\title{
Fen Eğitiminde İşbirlikli Öğrenme Kuramı, Buluş Yoluyla Öğrenme Stratejisi ve Yapılandırmacı Yaklaşım Basamaklarının Akademik Başarı Üzerinde Etkisinin Karşılaştırılması ${ }^{1}$
}

\author{
Sakine Serap AVGIN \\ Prof. Dr., Kahramanmaraş Sütçü İmam Üniversitesi, \\ Eğitim Fakültesi, Matematik ve Fen Bilimleri Eğitimi Bölümü \\ ssavgin@ksu.edu.tr \\ Orcid ID: https://orcid.org/0000-0002-4845-9799

\section{Büşra UYGUN} \\ Kahramanmaraş Sütçü İmam Üniversitesi, Eğitim Fakültesi, \\ Matematik ve Fen Bilimleri Eğitimi Bölümü, Yüksek Lisans Öğrencisi \\ busrauygn7@gmail.com \\ Orcid ID: https://orcid.org/0000-0002-6981-2205
}

\section{Öz}

Araştırmanın amacı, işbirlikli öğrenme kuramı, buluş yoluyla öğrenme stratejisi ve yapılandırmacı yaklaşım kuramı basamaklarının bireylerin akademik başarılarına etkisinin karşılaştırılmasıdır. Araştırma; ön test-son test modeline uygun Kahramanmaraş ilinde, MEB'e bağlı okullarda bulunan 7. sinıf öğrencileriyle yarı deneysel bir çalışma olarak yapılmıştır. Akademik başarıları birbirine yakın olan dört grup seçilmiş ve bu dört grup içinden üç deney ve bir kontrol grubu atanmıştır. Kontrol grubuna geleneksel öğretim yöntemi uygulanmıştır. Deney grupları olarak, işbirlikli öğrenme kuramı, buluş yoluyla öğrenme stratejisi ve yapılandırmacı yaklaşım basamaklarının uygulanacağı üç grup seçilmiştir. Çalışma her bir deney grubuna 4 haftalık süre boyunca uygulanmıştır. Uygulamaların öncesi ve sonrasında her iki gruba da Fen Bilgisi Başarı Testi ön-test ve son-test olarak uygulanmıştır. Veriler bağımsız $t$ testi ile değerlendirilmiştir. Elde edilen verilere göre yapılandırmacı yaklaşım basamaklarının kullanıldığ deney grubu ile kontrol grubu arasındaki p anlamlılık değeri 0,24 , buluş yoluyla öğrenme stratejisinin kullanıldığ 1 deney grubu ile kontrol grubu arasındaki p anlamlılık değeri 0,002, işbirlikli öğrenme kuramının kullanıldığ deney grubu ile kontrol grubu arasındaki p anlamlılık değeri 0,001 olarak bulunmuştur. $\mathrm{P}$ anlamlılık değerleri $\mathrm{p}<0,005$ olan deney ve kontrol

\footnotetext{
${ }^{1}$ Makale Geliş/Kabul Tarihi: 27.02.2020 / 26.04.2021

Künye Bilgisi: Avgın, S.S. ve Uygun, B. (2020). Fen eğitiminde işbirlikli öğrenme kuramı, buluş yoluyla öğrenme stratejisi ve yapılandırmacı yaklaşım basamaklarının akademik başarı üzerinde etkisinin karşılaştırılması. Kahramanmaraş Sütçü Imam Üniversitesi Sosyal Bilimler Dergisi, 18 (1), 1-16. DOI: 10.33437/ksusbd.695473
} 
grupları arasında anlamlı farklılık bulunmaktadır. Akademik başarıları ve $\mathrm{p}$ anlamlılık değerleri karşılaştırıldığında en fazla başarı işbirlikli öğrenme kuramı uygulanan grupta görülmüştür ve bu doğrultuda önerilerde bulunulmuştur.

Anahtar Kelimeler: İşbirlikli Öğrenme Kuramı, Buluş Yoluyla Öğrenme Stratejisi, Yapılandırmacı Yaklaşım Basamakları, Geleneksel Öğretim Yöntemi, Fen Bilimleri.

\title{
Comparison of Cooperative Learning Theory, Discovery Learning Strategy and Constructivist Approach Steps on Academic Achievement in Science Education
}

\begin{abstract}
The aim of the study is to compare the effects of cooperative learning theory, discovery learning strategy and constructivist approach steps on students' academic achievement. Research; It has been conducted as a semi-experimental study with 7th grade students in schools affiliated to the Ministry of National Education in Kahramanmaraş, in accordance with the pre-test-post-test model. Four groups with similar academic achievements have been selected and three experimental and one control group have been assigned from these four groups. Traditional teaching method has been applied to the control group. As the experimental groups, three groups in which cooperative learning theory, discovery learning strategy and constructivist approach steps will be applied have been selected. The study has been applied to each experimental group for a period of 4 weeks. Science Achievement Test has been applied as pre-test and post-test to both groups before and after the applications. The data have been evaluated by independent t test. According to the data obtained, the $\mathrm{p}$ significance value between the experimental group using the constructivist approach steps and the control group has been 0.24 , the p significance value between the experimental group using the discovery learning strategy and the control group has been 0.002 , the p significance value between the experimental group using the cooperative learning theory and the control group It has been found to be 0.001 . There is a significant difference between the experimental and control groups whose $\mathrm{p}$ significance values are $\mathrm{p}<0.005$. When their academic achievement and $\mathrm{p}$ significance values have been compared, it has been seen that the group who applied the cooperative learning theory had the highest success, and suggestions have been made in this direction.
\end{abstract}

Keywords: Cooperative Learning Theory, Discovery Learning Strategy, Constructivist Approach Steps, Traditional Teaching Method, Science. 


\section{GİRIŞ}

Eğitim bir bireyin yeteneklerinin ortaya çıkması, beceri, tutum ve kültürel değerlerinin geliştirilmesi, estetik yönden duyarlılık kazanması ve davranışlarının olumlu hale gelmesini sağlamayı içeren süreçler bütünüdür. Bireyin aldığı eğitimi günlük hayatında kullanabilmesi, bilgilerinin kalıcı hale getirilmesi ve gelişen dünyaya ayak uydurabilmesi eğitim sisteminin temel esaslarından biridir (MEB, 2018: 4).

Öğrenme düzeylerini daha üst seviyelere çıkarmak için etkili öğretim yöntem ve teknikleri tespit edilerek doğru bir şekilde kullanılmalıdır. Burada en önemli görev bu yöntemleri kullanacak olan öğretmenlerindir. Öğrenciyi her yönüyle etkileyen, derste aktif kılan, ezbere değil bilgiyi anlamlandırarak öğreten ve sinıf ortamında ki öğrenmeleri daha verimli hale getiren bir yöntem seçilmelidir (Arslan, 2020: 44 ). Yirminci Yüzyıl'da planlanan eğitim, çağın gereksinimi olan "bilgiyi üreten", "bilgiyi kullanan" ve "problem çözebilen" bireyler yetiştirmeyi amaçlamaktadır. Bunun sonucunda da eğitimin önemi eskiye oranla daha da fazla artmıştır (Koca, 2014: 1).

Gelişen dünyada her geçen gün nitelikli insan gücüne olan ihtiyaç artmaktadır. Buna bağlı olarak ülkemizde 6-14 yaş grubunda ki öğrencilerin zorunlu eğitimleri kapsamında ki fen bilimleri eğitiminin nitelikli insan yetiştirme boyutunda ki yeri önem kazanmaktadır. Fen bilimleri eğitimi ve sosyal bilimler eğitimi bu kapsamda diğer bütün derslerin yapı taşını oluşturmaktadır (Kaptan ve Korkmaz, 2000: 6).

Fen bilimleri dersi öğrencilerin çevrelerinde olup bitenleri fark etmelerine, Dünya'yı tanıyıp sevmelerine yardımcı olur. Öğrencilere iletişim becerisi kazandırarak aile, arkadaş ve öğretmenleriyle daha etkili ve doğru iletişim kurmalarını sağlar. Çocuklara yapılması gereken karakter eğitimi, fen eğitimi sayesinde daha kolay bir şekilde yapılabilir. Çocuk her an çevresinde bulunan kişi ve nesnelerle etkileşim halindedir (Hançer vd., 2003: 81)

Fen eğitimi çocuğun dil gelişimini sağlayarak bu etkileşimi daha kolay hale getirir. Dili gelişen bir çocuk, mantık yürütme yetisinde de gelişim gösterir. Bu şekilde mantığı gelişen bir bireyler çevresinde ki problemlere de çözüm odaklı olarak yaklaşırlar ve kendi kendilerine öğrenme kontrolünü de çok daha kolay sağlayabilirler. $\mathrm{Bu}$ olguları sağlayan öğrencilerin fen becerileri gelişmiş olacaktır. Fen becerisi gelişen bir ögrenci ise günlük hayatta ki diğer becerilerini de geliştirecektir. Öğrencilerin sadece fen eğitimini değil diğer dersleri de öğrenmeleri kolaylaşarak başarı düzeyleri artacaktır. Böylece öğrenciler kendi yeteneklerinin farkına vararak öğrenmeyi öğreneceklerdir. 
$\mathrm{Bu}$ doğrultu da fen dersinin öğrencilere bu özellikleri kazandırması için her geçen gün farklı teknik ve yöntemler araştırılmaktadır. Bu yöntemler öğrencilerin konuları daha iyi anlamaları, öğrendikleri bilgileri daha kalıcı hale getirmeleri, okulda öğrenilenleri günlük hayatla ilişkilendirebilmeleri için araştırılıp geliştirilmiştir. $\mathrm{Bu}$ yöntem ve teknikler okulun araç-gereç durumuna, sınıfta uygulanabilirliklerine ve konulara göre farklılık göstermektedir. Bir konu da hangi teknik kullanılmalı üzerine yapılan araştırmalarda birçok konunun farklı tekniklerle anlatılması üzerine sayısız araştırma yapılmıştır. Özellikle yapılandırmacı yaklaşım kuramı, buluş yoluyla öğrenme stratejisi, işbirlikli (kubaşık) öğrenme kuramının fen bilimleri dersine olan katkısı üzerine araştırmalar yapılmıştır.

\section{Buluş Yolu İle Öğrenme Stratejisi}

Buluş yoluyla öğrenme stratejisi Bruner tarafından 1960'lı yıllarda geliştirilmiş ve öğrencilerin zihinsel gelişmişlik seviyesine göre üç farklı şekilde uygulanmasını önerilmiştir. Bunlar;

- Serbest buluş yoluyla öğretim,

- Yar1-serbest buluş yoluyla öğretim,

- Bağımlı buluş yoluyla öğretim olmak üzere üçe ayrılır.

Serbest buluş yoluyla öğretimde öğretmen öğrencilere bir problemi veya problemin çözüm yollarını vermez. Öğrenciler hem problemi kurar hem de çözüm yollarını tamamen kendileri bulur. Burada öğretmenin görevi öğrencilerin çalışmaları bittikten sonra gerekli kontrolleri yaparak öğrencilere dönüt sağlamaktır. Bilişsel gelişim düzeyi yüksek olan öğrencilerde bu yöntem uygulanır. Yarı-serbest buluş yoluyla öğretimde öğretmenin görevi öğrencilere konuyla alakalı problem kurmaktır. Problemi bilen öğrenciler bu problemin çözümünde ki yöntemleri ve problemin çözümünü kendileri bulurlar. Bu yöntem bilişsel gelişim düzeyi normal ve bilişsel süreç becerileri yeterince gelişmiş olan öğrencilerin oluşturduğu sınıflarda uygulanır. Bağımlı buluş yoluyla öğretim yönteminde ise öğretmen öğrencilere problemi kurar, çözüm için izlenecek yolları belirler. Burada öğrenciye düşen görev öğretmenin kurduğu probleme yine öğretmenin belirlediği çözüm yollarından çözüm üretmektir. Bağımlı buluş yoluyla öğretim yöntemi bilişsel gelişim seviyesi düşük olan ve bilişsel süreç becerileri yeterince gelişmemiş olan öğrenci grubunun bulunduğu sinıflarda uygulanır (Özmen, 2004: 101). 


\section{İşbirlikli (Kubaşık) Öğrenme Kuramı}

İşbirlikli öğrenme kuramı öğrencilerin bir ortak amaç dâhilinde karma gruplar oluşturup akademik bir konu belirleyerek birbirlerinin öğrenmelerine yardımc1 olacak bir ortam oluşturmaları olarak tanımlanır (Doymuş vd., 2004: 104). İşbirlikli öğrenme kuramı, bireylerin bilgileri ezberleyerek değil yaparak yaşayarak, yeni bilgiler ile eskileri sentezleyip kendi öğrenmelerini sağlayarak bilgiyi kalıcı hale getirmelerine yardımc1 olur. $\mathrm{Bu}$ şekilde bireylerin, bilişsel yeterliliği en üst düzeye çıkar (Güngör ve Açıkgöz, 2005: 359). İşbirlikli öğrenme kuramında öğrenciler belirlenmiş bir konu veya problemin üzerinde grupla birlikte düşünürler, tartışırlar ve çözüm yolları üretmeye çalışırlar. Her öğrencinin değerlendirmesi grupla ortak bir şekilde yapılır. Bundan dolay1 öğrencilerin hepsi üstlerine düşen görevi yerine getirmeye çalışırlar. $\mathrm{Bu}$ da işbirlikli öğrenmenin amacını oluşturması için gerekli olan bir şarttır. İşbirlikli öğrenme kuramı öğrencinin sadece akademik başarısını değil sosyal yönden değişim ve gelişimini de olumlu yönde etkiler (Doymuş vd., 2005: 66).

İşbirlikli öğrenme kuramında öğrenciler grup halinde ve işbirlikli olarak çalışmak zorunda olduklarından dolayı birbirlerine yardım etme davranışları olumlu yönden gelişmiş olur. Bu yardımlaşma sürecinde öğrenciler birlikte değerlendirilecekleri için problemi veya konuyu daha iyi anlayan öğrenci diğer arkadaşlarına kendi düşüncelerini aktarmaya çalışacaktır. Bunun için problemi tekrar düzenler, çözümü hakkında bilgiler vermek gibi açıklamalar yapar. $\mathrm{Bu}$ durumda hem yardım eden hem de yardım alan olumlu yönde etkilenir. $\mathrm{Bu}$ yardımlaşmalar öğrencilere yeni bir boyut ve bakış açısı kazandırır (Doymuş vd., 2005: 62).

\section{Yapılandırmacı Yaklaşım Kuramı}

Yapılandırmacı yaklaşım son yıllarda eğitim anlayışında adından çok sık söz ettiren güncel yaklaşımlardan biridir. Özellikle eğitim alanında tartışma konusu olan yapılandırmacılığın bu kadar çok dikkat çeken bir yaklaşım olmasının temel nedenleri de ancak bu yaklaşımın doğru bir şekilde anlamlandırılması ile mümkün olabilir (İnceağaç, 2020: 78).

Yapılandırmacı yaklaşım, öğrencilerin öğrendiği bilgileri aynen almayarak kendi bilgileriyle zihinlerinde yapılandırma süreçleridir. Bu öğrenme yönteminde öğrencilerin daha önce ki yaşantıları temel alınır. Öğrenilen bilgi dar bir kalıpta, belirli bir konu alanına bağlı olarak değil de öğrencilerin zihinlerinde oluşturduğu şekilde yapılandırılarak var olur (Balcı, 2007: 7). Yapılandırmacı yaklaşım süreçleri altı alt basamak şeklinde öğrenciye sunulur. Bunlar;

"1. Olayın sunumu 
2. Ön bilgilerin hatırlatılması ve alternatif kavramların belirlenmesi

3. Hipotez kurma

4. Veri toplama

5. Hipotezlerin test edilmesi ve kavram oluşturma

6. Genelleme yapma” (Köseoğlu ve Kavak, 2001: 145).

$\mathrm{Bu}$ çalışmanın amacı, ilköğretim 7. Sınıf öğrencilerinin "Canlılarda üreme, büyüme ve gelişme” konusunda, buluş yoluyla öğrenme stratejisi, işbirlikli ögrenme kuramı ve yapılandırmacı yaklaşım basamaklarıyla anlatılan derslerde ki akademik başarının karşılaştırılmasını yapmak ve hangi yaklaşım kullanıldığında bireylerin akademik başarısının daha fazla olacağını ölçmektir. $\mathrm{Bu}$ yaklaşımların fen dersinde ki akademik başarısına etkisi tek tek araştırılmış fakat hangisinin fen dersi üzerinde ki akademik başarıya etkisi üzerinde daha etkili olduğu karşılaş̧ırılmamıştır. Çalışmanın amacı doğrultusunda alanyazında ki bu eksikliğin giderilmesi hedeflenmiştir.

\section{YÖNTEM}

$\mathrm{Bu}$ araştırmada, kontrol gruplu ön-test son-test yar1-deneysel deseni kullanılmıştır. Yarı deneysel desende gruplar tamamen rastgele oluşturulur. $\mathrm{Bu}$ gruplara seçilen bireylerde tamamen rastgele seçilerek gruplar belirlenir. Gruplar deney ve kontrol grubu olacak şekilde yine rastgele ikiye ayrilır ve nitelikleri birbirine benzer bireyler seçilir.

Araştırma bir kontrol grubu ve üç adet deney grubu olmak üzere toplam dört gruptan oluşmaktadır. Deney öncesi dört gruba da ön test kapsamında başarı testi uygulanmıştır. Gruplar ön test sonuçlarına göre ortalamaları birbirlerine yakın olacak şekilde oluşturulmuştur.

Araştırma yapılırken birinci gruba işbirlikli öğrenme kuramı, ikinci gruba buluş yoluyla öğrenme stratejisi, üçüncü gruba yapılandırmacı yaklaşım basamakları kullanılarak ders anlatılmıştır. Son grup ise kontrol grubu olarak belirlenerek geleneksel öğretim yöntemi kullanılarak ders anlatılmıştır.

Deneysel işlemlerin gerçekleştirilmesinden sonra her gruba başarı testi tekrar uygulanmıştır. Uygulamaya katılan öğrencilerin hazır bulunuşlukları birbirine yakındır. Araştırma 2018-2019 eğitim-öğretim yılı bahar döneminde, Kahramanmaraş'ın Türkoğlu ilçesinde bulunan bir ortaokulun 7. sınıf öğrencileri ile gerçekleştirilmiştir. Konu olarak 7. sınıf fen bilimleri kitabındaki 6. ünite olan canlılarda üreme, büyüme ve gelişme ünitesi seçilmiştir. Kazanımların ele alınmasıyla birlikte çalışma süresi 4 hafta olarak seçilmiştir. Başarı testi olarak 
MEB'in 2017-2018 ve 2018-2019 yılında ünite değerlendirmesi olarak yayımladığı sorular uygulanmıştır.

\section{Problem Cümlesi}

Fen Bilimleri dersinde 7. sınıf düzeyinde yer alan canlılarda üreme, büyüme ve gelişme ünitesinin, işbirlikli öğrenme kuramı, buluş yoluyla öğrenme stratejisi ve yapılandırmacı yaklaşım basamakları kullanılarak anlatılan derslerin, birbirlerinin ve kontrol grubunun akademik başarıları arasında anlamlı bir farklılık var mıdır?

\section{Evren ve Örneklem}

$\mathrm{Bu}$ araştırmanın evreni, ortaokul 7. Sınıfta öğrenim gören öğrencilerdir. Örneklem ise, Kahramanmaraş'ın Türkoğlu ilçesinde bulunan bir ortaokulda 7. sınıfta öğrenim gören 56 öğrenciden oluşmaktadır.

\section{Deneysel İşlem Basamakları}

1. Uzman görüşü alınarak konu ile ilgili MEB' in 2017-2018 ve 2018-2019 yılında ünite değerlendirmesi olarak yayımladığı sorular öğrencilere ön test olarak uygulanmış ve bu sonuçlara göre öğrencilerin aritmetik ortalamaları birbirine yakın olacak şekilde deney ve kontrol grupları oluşturulmuştur.

2. Birinci deney grubu için;16 ders saatini kapsayan işbirlikli kuramının kullanıldığ 1 ders planı hazırlanmış ve bu konuda uzman görüşleri alınmıştır. $\mathrm{Bu}$ deney grubunda öğrenciler gruplar haline getirilmiştir. Gruplar oluşturulurken kız ve erkek öğrenci sayısının gruplarda dengeli bir şekilde dağılmasına, öğrencilerin başarılarının farklı düzeylerde olmasına, sosyal ve kültürel bakımdan farklılık taşıyan öğrencilerin bir araya gelmesine dikkat edilmiştir. Öğrencilerden gruplarına ortak bir karar verilerek bir isim bulunması istenmiştir. Öğretmen dersin işleneceği haftadan bir hafta önce bu grupları oluşturup grup isimleri belirledikten sonra öğrencilerden araç ve gereçler istemiştir. Her gruptan farklı araç gereçler olmak kaydıyla; birinci gruptan hayvanlarda üreme, büyüme ve gelişme, ikinci gruptan insanlarda üreme, büyüme ve gelişme ve üçüncü gruptan bitkilerde ürüme, büyüme ve gelişme ile ilgili fotoğraflar bulmalarını, bunları sunacak araç-gereçler getirmelerini ve konularla alakalı araştırmalar yapmalarını istemiştir.

Öğretmen araştırma sırasında öğrencilerin gruplar halinde oturmasını ve sınıf düzenini de buna göre oluşturulmasını sağlamıştır. Daha sonra öğretmen öğrencilere getirdikleri fotoğraflarla araştırdıkları konu hakkında afişler hazırlamalarını ve sınıfta arkadaşlarına grup halinde sunmalarını istemiştir. Her grup sunumunu sınıf arkadaşlarına yaptıktan sonra öğretmen konu hakkında 
sonuç çıkararak doğru bilgiye ulaşmalarını sağlamıştır ve tüm grupların sunumları bittikten sonra değerlendirmeler yapmıştır. Değerlendirmeler bireysel performansa bakılmaksızın grup ortak değerlendirmesi olarak yapılmıştır.

3. İkinci deney grubu için; 16 ders saatini kapsayan buluş yoluyla öğrenme stratejisinin kullanıldığı ders planı hazırlanmış ve bu konuda uzman görüşleri alınmıştır. Bu deney grubunda öğretmen yarı- serbest buluş yoluyla öğretim tekniğini kullanmıştır. Problemi öğretmen kurmuş çözüm yolları ve çözümü öğrenciler bulmuştur. Öğretmen derse başlarken konular hakkında öğrencileri bilgilendirmemiştir. Öğrencilere tümevarım yöntemini uygulayarak sonuca kendi kendilerine ulaşmalarını sağlamıştır. Öğretmen öğrencilere sürekli konuyla alakalı basitten karmaşığa gidecek şekilde sorular yöneltmiş ve problemler kurmuş̧ur. Soruların sonucunda öğrencilerin söyledikleri bazı kilit kavramları tahtaya yazmıştır. Daha sonra bu kavramların tam anlamlarını bulana kadar öğrencilere sorular yöneltmiştir. Sonuç olarak öğrenciler doğru bilgiye kendileri ulaşmıştır.

4. Üçüncü deney grubu için; 16 ders saatini kapsayan yapılandırmacı yaklaşım basamaklarının kullanıldığı ders planı hazırlanmış ve bu konuda uzman görüşleri alınmıştır. Bu yaklaşımın basamaklarını kullanan öğretmen dersin başlangıcında öğrencilere konuları ve konular içerisinde ki kavramları vermiştir. $\mathrm{Bu}$ kavramların tanımını yapmadan konu ve kavramla alakalı öğrencilerin yanlış veya eksik olan bilgilerinin ortaya çıkması için sorular yöneltmiştir. Soruları sürekli tekrarlayıp yanlış bilgilerini ortaya çıkaran öğretmen öğrencilerin söylediği tüm kavram ve yanlış tanımlarını tahtaya yazmıştır. Daha sonra doğru bilgileri öğrencilere sunmuştur ve tahtada yanlış yazan bilgi ve doğru bilgiyi karşılaştırarak öğrencilerin iki cevap arasında bir bağ kurup kendi zihninde yapılandırmalarını sağlamıştır. Sonuç olarak öğrenci bilgiyi kendi zihninde yapılandırarak öğrenmiştir.

5. Kontrol grubu için; 16 ders saatini kapsayan geleneksel yönteminin kullanıldığ 1 ders planı hazırlanmış ve bu konuda uzman görüşü alınmıştır. Öğretmen derse konunun adını ve kavramların tanımını vererek başlamıştır. Tanımdan sonra konuyu sunum şeklinde anlatmıştır. Konu sonunda öğrencilere sorular sorarak değerlendirme yapmıştır.

6. Deney ve kontrol gruplarına aynı öğretmen tarafından hazırlanan ders planları hazırlanmış yine aynı öğretmen tarafından uygulama yapılmıştır.

\section{Verilerin Toplanması}

Başarı testi deney ve kontrol gruplarına hem ön test hem de son test olarak uygulanmıştır.7. Sınıf fen bilimleri dersinde canlılarda üreme, büyüme ve gelişme konularına ilişkin Milli Eğitim Bakanlığı'nın belirlemiş olduğu hedef ve 
kazanımlar alınmıştır. Bu hedef ve kazanımlara göre başarı testi soruları, MEB' in 2017-2018 ve 2018-2019 Fen Bilimleri ders kitabında yer alan canlllarda üreme, büyüme ve gelişme ünitesi, ünite değerlendirme soruları kullanılmıştır. Deney ve kontrol gruplarına uygulanan başarıyı ölçme testinde bulunan sorular 20 soru ile sinırlıdır.

Başarı testinde her doğru yanıta 1 puan, her yanlış yanıta 0 puan verilmiştir.

Testten alınabilecek en yüksek puan 20, en düşük puan 0 olarak belirlenmiştir.

\section{Verilerin Çözümlenmesi}

Deneysel işlemin etkili olup olmadığı iki farklı analiz ile tespit edilmiştir. Bunlardan ilki, deney ve kontrol grubunun ön-testlerinin, ikincisi son-testlerinin karşılaştırılmasıdır. Buradaki karşılaştırmada iki grubun ortalama puanları arasındaki farkın anlamlı olup olmadığı bağımsız t-testi ile sınanmıştır. P (önem) değerinin anlamlılık düzeyi 0.05 olarak alınmıştır.

\section{BULGULAR}

Araştırmada belirlenen modele göre; uygulamadan önce ve sonra her dört gruba da uygulanan başarı testlerinin analiz sonuçları aşağıdaki tablolarda verilmiştir.

Tablo 1. İşbirlikli öğrenme Kuramı Uygulanan Deney Grubu ve Geleneksel Öğretim Yöntemi Uygulanan Kontrol Grubu Ön-Test ve Son-Testinden Elde Edilen Verilerin Bağımsız T-Testi Analiz Sonuçları.

\begin{tabular}{|c|l|l|l|l|l|l|}
\hline Testler & Gruplar & $\mathbf{N}$ & $\mathbf{X}$ & Ss & $\mathbf{t}$ & \multicolumn{1}{|c|}{$\mathbf{P}$} \\
\hline \multirow{2}{*}{ Ön-test } & Kontrol & 14 & 5,57 & 1,01 & \multirow{2}{*}{$-1,38$} & \multirow{2}{*}{0,16} \\
\cline { 2 - 6 } & Deney & 14 & 6,14 & 1,74 & & \\
\hline \multirow{2}{*}{ Son- test } & Kontrol & 14 & 5,92 & 2,30 & \multirow{2}{*}{3,22} & \multirow{2}{*}{0,001} \\
\cline { 2 - 5 } & Deney & 14 & 9,00 & 2,71 & & \\
\hline
\end{tabular}

Tablo 1'deki verilere bakıldığında ilgili ünitenin konuları anlatılmadan önce uygulanan ön-testlerde deney ve kontrol gruplarının ortalama puanları arasında istatistiksel olarak önemli bir farkın olmadığ $1(\mathrm{p}>0,05)$ görülmektedir. Konular anlatılıp deneysel işlem basamakları uygulandıktan sonra uygulanan son-test analiz sonuçlarına bakıldığında işbirlikçi öğrenme kuramının uygulandığı deney grubu ile geleneksel öğrenme yönteminin uygulandığ kontrol grubu ortalama 
puanları arasında istatistiksel olarak önemli bir farkın olduğu $(\mathrm{p}<0,05)$ görülmektedir.

Tablo 2. Buluş yoluyla Öğrenme Stratejisi Uygulanan Deney Grubu Ve Geleneksel Öğretim Yöntemi Uygulanan Kontrol Grubu Ön-Test Ve SonTestinden Elde Edilen Verilerin Bağımsız T-Testi Analiz Sonuçları

\begin{tabular}{|c|l|l|l|l|l|l|}
\hline Testler & Gruplar & $\mathbf{N}$ & $\mathbf{X}$ & \multicolumn{1}{|c|}{ Ss } & $\mathbf{t}$ & $\mathbf{p}$ \\
\hline \multirow{2}{*}{ Ön-test } & Kontrol & 14 & 5,57 & 1,01 & \multirow{2}{*}{$-1,67$} & \multirow{2}{*}{0,10} \\
\cline { 2 - 5 } & Deney & 14 & 6,28 & 1,68 & & \\
\hline \multirow{2}{*}{ Son- test } & Kontrol & 14 & 5,92 & 2,30 & \multirow{2}{*}{2,97} & 0,002 \\
\cline { 2 - 5 } & Deney & 14 & 9,28 & 3,53 & & \\
\hline
\end{tabular}

Tablo 2' deki verilere bakıldığında ilgili ünitenin konuları anlatılmadan önce uygulanan ön-testlerde deney ve kontrol gruplarının ortalama puanları arasında istatistiksel olarak önemli bir farkın olmadığ $1(p>0,05)$ görülmektedir. Konular anlatılıp deneysel işlem basamakları uygulandıktan sonra uygulanan son-test analiz sonuçlarına bakıldığında buluş yoluyla öğrenme stratejisinin uygulandığ 1 deney grubu ile geleneksel öğrenme yönteminin uygulandığ 1 kontrol grubu ortalama puanları arasında istatistiksel olarak önemli bir farkın olduğu $(p<0,05)$ görülmektedir.

Tablo 3. Yapılandırmacı Yaklaşım Kuramı Basamakları Uygulanan Deney Grubu Ve Geleneksel Öğretim Yöntemi Uygulanan Kontrol Grubu Ön-Test Ve

Son-Testinden Elde Edilen Verilerin Bağımsız T-Testi Analiz Sonuçları

\begin{tabular}{|c|l|l|l|l|l|l|}
\hline Testler & Gruplar & \multicolumn{1}{|c|}{$\mathbf{N}$} & $\mathbf{X}$ & Ss & \multicolumn{1}{|c|}{$\mathbf{T}$} & \multirow{2}{*}{$\mathbf{P}$} \\
\hline \multirow{2}{*}{ Ön-test } & Kontrol & 14 & 5,57 & 1,01 & \multirow{2}{*}{$-1,19$} & \multirow{2}{*}{0,23} \\
\cline { 2 - 5 } & Deney & 14 & 6,28 & 2,64 & & \\
\hline \multirow{2}{*}{ Son- test } & Kontrol & 14 & 5,92 & 2,30 & \multirow{2}{*}{1,16} & \multirow{2}{*}{0,24} \\
\cline { 2 - 5 } & Deney & 14 & 7,00 & 2,57 & & \\
\hline
\end{tabular}

Tablo 3’teki verilere bakıldığında ilgili ünitenin konuları anlatılmadan önce uygulanan ön-testlerde deney ve kontrol gruplarının ortalama puanları arasında istatistiksel olarak önemli bir farkın olmadığ $1(p>0,05)$ görülmektedir. Konular anlatılıp deneysel işlem basamakları uygulandıktan sonra uygulanan son-test 
analiz sonuçlarına bakıldığında yapılandırmacı yaklaşım kuramı basamaklarının uygulandığı deney grubu ile geleneksel öğrenme yönteminin uygulandığı kontrol grubu ortalama puanları arasında istatistiksel olarak önemli bir farkın olmadığ 1 ( $>0,05)$ görülmektedir.

\section{TARTIŞMA VE SONUÇ}

Bu çalışmanın amacı fen bilimleri dersinde işbirlikli öğrenme kuramı, buluş yoluyla öğrenme stratejisi ve yapılandırmacı yaklaşım kuramı basamakları kullanılarak anlatılan derslerin öğrencilerin akademik başarılarına olan etkisinin karşılaştırılmasıdır. Akademik başarılarının karşılaş̧ırılması ön-test, son-test veri analizlerine göre;

Tablo 1' de deney grubu olan işbirlikli öğrenme kuramı ve kontrol grubu olan geleneksel öğrenme yöntemi grupları ön-test sonuçları arasında anlamlı bir farklılık olmadığ 1 görülmüsstür. Fakat uygulama sonucunda Tablo 1' de bulunan son-test sonuçlarına göre deney grubu olan işbirlikli öğrenme kuramı ve kontrol grubu olan geleneksel öğrenme yöntemi grupları arasında anlamlı bir farkl1lık olduğu görülmüsstür. Deney grubunda başarının daha fazla olmasının nedeni öğrencilerin arkadaşlarıyla birlikte işbirlikli bir şekilde ve grupta ki bütün üyelerin birbirlerine anlaşılmayan veya unutulan noktalarda hatırlatmalar yaparak çalışmalarıdır. İşbirlikli öğrenmede öğrenciler bireysel performanslarına bakılmaksızın grup performansına göre değerlendirildiği için öğrenciler kendi başarılarının haricinde grupta ki arkadaşlarının da başarılarına odaklanırlar. Grubun başarılı olabilmesi için her öğrenci bilgilerini arkadaşlarıyla paylaşmak durumundadır. $\mathrm{Bu}$ şekilde yardımlaşma değerini de kazanmış olacaklardır. Çalışma yapılırken de araştırmacının gözlemlemeleri sonucu öğrenci gruplarının birbirleri arasında kaynaşmalarının olduğu, öğrencilerin sabırla birbirlerine yardım etmeye çalıştıkları, uyumsuzluk yaşayan öğrenciyi ikna ederek çalışmalarına aldıkları, birbirlerini süreye uymak, uyumlu olmak ve doğru sonuca ulaşmak için sürekli uyardıkları gözlemlenmiştir.

Tablo 2'de deney grubu olan buluş yoluyla öğrenme stratejisi ve kontrol grubu olan geleneksel yöntemi grupları ön-test sonuçları arasında anlamlı bir farklılık olmadığı görülmüştür. Fakat uygulama sonucunda Tablo 2' de bulunan son-test sonuçlarına göre deney grubu olan buluş yoluyla öğrenme stratejisi ve kontrol grubu olan geleneksel yöntem grupları arasında anlamlı bir farklılık olduğu görülmüştür. Deney grubu öğrencileri doğru bilgiye kendi düşünme ve araştırmaları sonucu ulaştıkları için akademik başarı düzeyleri geleneksel yöntemle anlatılan derse göre daha yüksek olmuştur. Bilgiyi direkt öğrenciye vermek yerine öğrencinin doğru bilgiye kendisinin ulaşmış olmasının tabloya göre akademik başarıyı olumlu yönde etkilediği görülmüştür. 
Tablo 3'te bulunan yapılandırmacı yaklaşım kuramı basamakları kullanılarak ders anlatılan deney grubu ve geleneksel öğrenme yöntemi kullanılarak ders anlatılan kontrol grubu ön -test sonuçları arasında anlamlı bir farklılık olmadığ 1 görülmüştür. Fakat uygulama sonucunda Tablo 3'te bulunan son-test sonuçlarına göre Yapılandırmacı yaklaşım basamakları kullanılarak ders anlatılan deney grubu ve geleneksel öğrenme yöntemi kullanılarak ders anlatılan kontrol grubu akademik başarıları karşılaştırıldığında aralarında anlamlı bir farklılık olmadığı görülmektedir. Bunun nedeni öğrencilerin canlllarda üreme, büyüme ve gelişme konusunda eski bilgileri ile yeni bilgilerini yeterince yapılandıramadıkları olabilir. Öğrencilerin ilgili üniteyle ilgili eksik veya yanlış bilgilerinin öğrendikleri yeni ve doğru bilgilerle kendi zihinlerinde yapılandırılma sürecinde başarılı olamadıkları görülmüştür.

Yöntemler ayrı ayrı incelendiğinde tablo 1 ve tablo 2 de bulunan işbirlikli öğrenme kuramı ve buluş yoluyla öğrenme stratejisi deney gruplarının kontrol grubuyla aralarında anlamlı bir farklılık olduğu görülmüsstür. Fakat tablo 3 'te bulunan yapılandırmacı yaklaşım basamaklarını kullanarak ders anlatılan grup ile kontrol grubu arasında anlamlı bir farklılık olmadığı gözlemlenmiştir. Çalışmanın ilk amacı bu üç yöntemin akademik başarı üzerinde etkilerini karşılaştırmaktır. İşbirlikli öğrenme kuramı, buluş yoluyla öğrenme stratejisi ve yapılandırmacı yaklaşım basamakları kullanılan derslerin akademik başarıları karşılaştırıldığında akademik başarısı en fazla olan grubun işbirlikli öğrenme kuramı uygulanan grup olduğu görülmüştür. Bu durum fen bilimleri dersinde canlılarda üreme, büyüme ve gelişme ünitesinde kullanılabilecek yöntem, kuram ve strateji arasında işbirlikli öğrenme kuramının öğrencilerin akademik başarısını artırdığı sonucuna ulaşılmıştır. Sonuç olarak; fen eğitiminde özellikle canlılarda üreme, büyüme ve gelişme ünitesinde işbirlikli öğrenme kuramı uygulandığında buluş yoluyla öğrenme stratejisi ve yapılandırmacı yaklaşım basamaklarının kullanılmasına göre akademik başarının olumlu yönde etkilenerek arttı̆̆ 1 görülmüştür.

Sarıkaya vd. (2010: 419)'nın fen bilgisi öğretmen adaylarının üzerinde yaptı̆̆ yapılandırmacı yaklaşımın öğrenci başarısına etkisi çalışmasında, yapılandırmacı yaklaşımın öğrencilerin akademik başarısında etkili olduğu sonucuna varılmıştır. Doymuş vd., (2004: 107) tarafindan yapılan fen dersinde işbirlikli öğrenmenin öğrencilerin akademik başarısına katkısını ölçen çalışma da, işbirlikli öğrenme ile anlatılan fen dersin de ki öğrencilerin akademik başarısının daha fazla olduğu sonucuna varılmıştır.

Kıncal, vd. (2007: 159)' un yaptıkları çalışmada fen bilgisi öğretiminde işbirlikli öğrenme kuramının kullanıldığı deney grubunun, geleneksel öğrenme yönteminin kullanıldığı kontrol grubuna göre akademik başarılarının daha yüksek olduğu ve iki grubun akademik başarıları arasında anlamlı düzeyde 
faklılık oluştuğu görülmüştür. Bu çalışmada elde edilen sonuçlar ile Kıncal, vd., (2007: 159)'un sonuçları birbiri ile paralellik göstermektedir.

Hevadanlı ve Akbayın (2006: 28)'ın biyoloji öğretiminde işbirlikli öğrenme kuramının başarı, hatırda tutma ve derse yönelik tutum üzerindeki etkilerini araştırmak amacıyla yaptıkları çalışmada işbirlikli öğrenme kuramının uygulandığı grup ve geleneksel öğretim yönteminin uygulandığı grup arasında akademik başarı açısından anlamlı farklılık olduğu görülmektedir. Yapılan çalışmada bu farklılığın işbirlikçi öğrenme yönteminin uygulandığı grup lehine olduğu ortaya çıkmıştır. Hevadanlı ve Akbayın, (2006: 28)'ın çalışmaları ile bu çalışma sonuçları benzerlik göstermektedir.

Ünal ve Ergin, (2006: 44)'nin buluş yoluyla fen öğretiminin öğrencilerin akademik başarılarına, öğrenme yaklaşımlarına ve tutumlarına etkisini araştırdıkları çalışmadan elde edilen bulgulardan, buluş yolu stratejisiyle fen bilgisi dersinin öğretildiği grubun geleneksel öğretim yöntemiyle öğretilen gruba oranla akademik başarısının daha yüksek olduğunu saptamışlardır. Bu çalışma da elde edilen sonuçlar ile Ünal ve Ergin, (2006: 44)'nin yaptığı çalışma sonuçları birbiriyle örtüşmektedir.

Teker vd. (2017: 847)'nin “'Işı̆̆ın ve sesin yayılması' ' ünitesini buluş yoluyla öğrenmenin öğrenci başarısı ve tutumuna etkisini ölçmek için 5. sınıf öğrencilerine yaptıkları çalışmada buluş yoluyla öğretim stratejisinin akademik başarıyı arttırmada ve öğrencilerin derse olan tutumlarında olumlu etkisi olduğu sonucuna varmışlardır. $\mathrm{Bu}$ sonuçla çalışmamızın sonucu paralellik göstermektedir.

Balcı (2007: 59)'nın ilköğretim 8. sınıf öğrencileri üzerinde yaptığ1 fen bilimleri dersinin belirli konularını öğrenme düzeyi ve fen bilimleri dersine olan tutum üzerine yaptığı çalışmada yapılandırmacı yaklaşımı ve geleneksel yaklaşımı karşılaştırmıştır. Araştırma sonucunda yapılandırmacı yaklaşım metodunun kullanıldığı grup lehine akademik açıdan ve fen bilgisi dersine yönelik olumlu tutumlar açısından anlamlı düzeyde fark bulunmuştur. Saygın vd., (2006: 58)'ın lise 1. sinıf öğrencileriyle biyoloji dersi üzerinde belirli konularda yaptıkları çalışmada yapılandırmacı öğretim yaklaşımı ile geleneksel öğretim yöntemini karşılaştırmış olup yapılandırmacı yaklaşım ile ders işlenen deney grubunun geleneksel yöntem ile ders işlenen kontrol grubuna göre akademik başarısının daha yüksek olduğu görülmüştür. Balcı (2007: 59)'nın, Saygın vd., (2006: 58)'ın çalışması ile bu çalışmada yapılan sonuçlar çelişmektedir.

Genç ve Şahin (2015: 389)'in yaptığı çalışmada da işbirlikli öğrenme kuramının öğrencinin akademik başarısını arttırmakla kalmamakta öğrencinin derse yönelik tutumunu, motivasyonunu ve kendisine olan güvenini de artırmakta olduğu sonucuna ulaşarak çalışmanın sonucunu desteklemiştir. 
Bahsedilen çalışmaların bir kısmı çalışmamızı desteklemekte bir kısmı desteklememektedir. Yapılan çalışmaların geneli yöntem, teknik ve stratejilerin geleneksel öğretimle kıyaslamasıdır. Hiçbir çalışmada işbirlikli öğretim kuramı, buluş yoluyla öğretim stratejisi, yapılandırmacı yaklaşım kuramı basamakları ve geleneksel öğretim yöntemlerinin kendi aralarında karşılaştırılması yapılmamış olup alanyazında bu eksikliğin giderilmesi amacıyla bu çalışma yapılmıştır.

\section{ÖNERILLER}

Yapılan çalışmaya göre fen eğitiminde işbirlikli öğrenme kuramının, buluş yolu stratejisi ve yapılandırmacı yaklaşım basamakları kullanılarak anlatılan derslere göre akademik başarı üzerindeki olumlu etkisi kanıtlanmıştır. İşbirlikli öğrenme kuramı sadece akademik başarıyı değil, sosyal gelişimi de desteklediği için öğrenciler hem akademik yönden başarı sağlamış olup hem de sosyal yönden gelişme göstermişlerdir. İşbirlikli öğrenme kuramı öğrenci merkezli bir kuram olduğu için öğrencilerin derse aktif katılımını sağlar. Bundan dolayı akademik başarıyı artırmakla kalmayıp öğrencilere fen bilimleri dersini sevdirerek öğrenilen bilgileri kalıcı hale getiren bir yöntemdir. Ayrıca farklı zekâ türlerine etki ederek tam öğrenmeyi de sağlamaktadır. Bu yüzden fen bilimleri derslerinde işbirlikli öğrenmenin kullanılması önerilebilir.

Çalışmanın da amacı olan işbirlikli öğrenme kuramı, buluş yoluyla öğrenme stratejisi ve yapılandırmacı yaklaşım basamaklarını kullanılarak anlatılan derslerde ki akademik başarı karşılaştırıldığı zaman özellikle canlılarda üreme, büyüme ve gelişme ünitesinde ki akademik başarı kıyaslamalarında işbirlikli öğrenme kuramının akademik başarı üzerinde olumlu etkisinin daha fazla olduğu görülmüştür. Bu durumdan yola çıkılarak fen bilimleri dersinin genelinde ve özellikle canlılarda üreme, büyüme ve gelişme ünitesinde işbirlikli öğrenme kuramının kullanılması önerilebilir.

İşbirlikli öğrenme kuramı doğru uygulandığında olumlu sonuçlar alındığı yapılan diğer çalışmalarda da kanıtlanmıştır (Genç ve Şahin, 2015: 389; Doymuş vd., 2004: 107; Kıncal vd., 2007: 159; Hevadanlı ve Akbayın, 2006: 28). Bu yöntemin doğru uygulanabilmesi için öncelikle üniversitelerde ki eğitim fakültelerinde öğrenim gören öğretmen adaylarına işbirlikli öğrenme kuramını detaylı bir şekilde ve uygulamalı olarak anlatılması önerilebilir. Ayrıca öğretmen adaylarının işbirlikli öğrenme kuramında tecrübe kazanabilmesi için okul deneyimi derslerinde de bu kuramın kullanılması önerilebilir.

Görevde bulunan öğretmenlerin işbirlikli öğrenme kuramının önemini fark ederek doğru bir şekilde uygulayabilmeleri için hizmet içi eğitim seminerlerinde bu kuramın önemi ve kullanım şekli hakkında bilgiler verilebilir. 
$\mathrm{Bu}$ önerilerin gerçekleştirilmesi durumunda fen bilimleri derslerinde ki akademik başarının artabileceği bu çalışmadan elde edilen veriler ile kanıtlanmıştır.

\section{KAYNAKÇA}

Arslan, A. (2020). İşbirlikli öğrenme modelinin eğitim-öğretim ortamlarında kullanımı. Ĕgitim Bilimleri, 42.

Balcı, A. S. (2007). Fen ögretiminde yapılandırmacı yaklaşım uygulmasının etkisi [Doctoral Dissertation], Selçuk Üniversitesi.

Bruner, J. S. (1960). The process of education. Harvard University Press.

Doymuş, K., Şimşek, Ü. ve Bayrakçeken, S. (2004). İşbirlikçi öğrenme yönteminin fen bilgisi dersinde akademik başarı ve tutuma etkisi. Journal Of Turkish Science Education, 1(2), 103-115.

Doymuş, K., Şimşek, Ü. ve Şimşek, U. (2005). A review on cooperative learning method: I. cooperative learning method and studies releated with this method. Erzincan Üniversitesi Eğitim Fakültesi Dergisi, 7(1), 59-83.

Genç, M. ve Şahin, F. (2015). İşbirlikli öğrenmenin başarıya ve tutuma etkisi. Necatibey Ĕgitim Fakültesi Elektronik Fen Ve Matematik Ĕ̆itimi Dergisi, 9(1), 375-396.

Güngör, A. ve Açıkgöz, K. Ü. (2005). İşbirlikli öğrenme ve geleneksel öğretimin okuduğunu anlama üzerinde etkileri ve cinsiyet ile ilişkileri. Kuram ve Uygulamada Ë̆itim Yönetimi, 43(43), 355-378.

Hançer, A. H., Şensoy, Ö. ve Yıldırım, H. İ. (2003). İlköğretimde çağdaş fen bilgisi öğretiminin önemi ve nasıl olması gerektiği üzerine bir değerlendirme. Pamukkale Üniversitesi Ĕ̈itim Fakültesi Dergisi, 13(13), 80-88.

Hevadanlı, M. ve Akbayın, H. (2006). Biyoloji öğretiminde işbirlikli öğrenme yönteminin başarı, hatırda tutma ve derse yönelik tutum üzerindeki etkileri. Dicle Üniversitesi Ziya Gökalp Eğitim Fakültesi Dergisi, (6), 2131.

İnceağaç, M. (2020). Eğitimde Yapılandırmacı Yaklaşım ve Görsel Sanatlar Eğitimi. Eğitim Bilimleri. 1. Bask1, Cetinje-Karadağ, 78-86.

Kaptan, F. ve Korkmaz, H. (2000). İlköğretimde fen bilgisi öğretimi, Illkögrretimde etkili ögretme ve öğrenme ögrretmen el kitabı. MEB Yayınevi. 
Kıncal, R. Y., Ergül, R. ve Timur, S. (2007). Fen bilgisi öğretiminde işbirlikli öğrenme yönteminin öğrenci başarısına etkisi. Hacettepe Üniversitesi Ĕ̈itim Fakültesi Dergisi, 32(32), 156-163.

Koca, M. K. (2014). Arazi çalışması temelli öğretim etkinliklerinin sosyal bilgiler dersine uygulanabilirliği. [Doktora Tezi, Gazi Üniversitesi Eğitim Bilimleri Enstitüsü], Ankara.

Köseoğlu, F. ve Kavak, N. (2001). Fen öğretiminde yapılandırıcı yaklaşım. Gazi Üniversitesi Gazi Eğitim Fakültesi Dergisi, 21(1).

Milli Eğitim Bakanlığı. (2017). 7. sınıf fen bilimleri ders kitabı 6. Ünite Ölçme Değerlendirme Soruları.

Milli Eğitim Bakanlığı. (2018). Fen bilimleri öğretim programı. Erişim Tarihi. 01.02.2018.

Milli Eğitim Bakanlığı. (2018). 7. sınıf fen bilimleri ders kitabı 6. Ünite Ölçme Değerlendirme Soruları

Özmen, H. (2004). Fen öğretiminde öğrenme teorileri ve teknoloji destekli yapılandırmacı (constructivist) ögrenme. The Turkish Online Journal Of Educational Technology, 3(1), 100-111.

Sarıkaya, M., Güven Yıldırım, E., Göksu, V. ve Aka İnce, E. (2010). Yapılandırmacı yaklaşımın öğrencilerin akademik başarı ve bilgilerinin kalıcılığg üzerine etkisi. İlkögretim Online (Elektronik), 9(1), 413-423.

Saygın, Ö., Altınboz, N. G. ve Salman, S. (2006). Yapılandırmacı öğretim yaklaşımının biyoloji dersi konularını öğrenme başarısı üzerine etkisi canlılığın temel birimi hücre. Gazi Üniversitesi Gazi Ĕgitim Fakültesi Dergisi, 26(1), 51-64.

Ünal, G. ve Ergin, Ö. (2006). Buluş yoluyla fen öğretiminin öğrencilerin akademik başarılarına, öğrenme yaklaşımlarına ve tutumlarına etkisi. Journal Of Turkish Science Education, 3.1: 36-52.

Teker, S., Kurt, M. ve Karamustafaoğlu, O. (2017). "Işı̆̆ın ve sesin yayılması" ünitesini buluş yoluyla öğrenmenin öğrenci başarısı ve tutumuna etkisi. Adyyaman Üniversitesi Sosyal Bilimler Enstitüsü Dergisi, (27), 835863. 